\title{
ACQUIRED RESISTANCE TO CORTICOTROPINS
}

\author{
BY \\ H. F. WEST* \\ Sheffield Centre for the Investigation and Treatment of Rheumatic Diseases
}

(RECEIVED FOR PUBLICATION APRIL 6, 1956)

Corticotropin, which may be defined as a pituitary extract that will directly stimulate the adrenal cortex to secrete its predominantly "glucocorticoid" hormones, has been in general use for about 5 years. In spite of this, its use as a therapeutic agent has not been defined. There are two reasons for this state of affairs. The first is that most physicians have assumed that the administration of synthetic corticosteroids (i.e. cortisone, delta-1 cortisone, etc.) amounts to the same thing as stimulating the adrenocortex. In consequence they have used only the more easily administered form of treatment. There is little evidence yet to prove or disprove this assumption, but on theoretical grounds it is not justified. The second reason is that much difficulty has been experienced in inducing and maintaining a therapeutic level of adrenocortical stimulation. This has discouraged physicians in their use of corticotropin and has prevented any valid trials of its use as a therapeutic agent. A study of the effects of prolonged adrenocortical stimulation upon the course of rheumatoid arthritis and ankylosing spondylitis was begun at this centre 3 years ago. After 18 months the therapeutic results were encouraging (West and Newns, 1955), but since that time the study has been brought almost to a halt because of the failure of the available "highly purified" corticotropins to maintain adrenocortical stimulation in many patients. Most of the observations made on acquired resistance to corticotropin that are reported below were incidental to this study. Forsham (1955) stated that he had not found the commercially available "highly purified" corticotropin gels to induce refractoriness or hypersensitivity, it being well known that the earlier preparations (not oxycellulose purified) did so.

In this paper evidence is presented which shows that on prolonged administration the development of refractoriness to highly purified corticotropin is common. In addition to refractoriness allergic

* Part-time Nuffield Research Fellow, University of Sheffield. reactions may occur that are not always harmless. Maddock, Leach, Tokuyama, Paulson, Nelson, Janget, and Heller (1956) reported the induction in man of non-species specific antigonadotrophins after the injection of pituitary gonadotrophin, which have apparently neutralized the patients' own $\stackrel{\sim}{\sim}$ gonadotrophins. If this can occur with one type 을

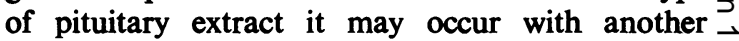
(i.e. corticotropin). Evidence relating to this $\subsetneq$ problem is presented and discussed. The question whether the adrenocorticotropic hormone itself is allergenic remains unsolved. The findings reported here have a direct bearing on this problem. Tife word allergen is used in this paper in its wide sense, since the nature of the altered reaction thes often occurs with prolonged administration of highty purified corticotropin has not been investigated.

\section{Materials and Methods}

The corticotropins used were Armour's High Purity (H.P.) Acthar Gel; Wilson's purified corticotrophin; Organon's purified Cortrophin-Z; Crooke's Zinc Protamine ACTH; and Duracton (Nordic Biochemicals Ltd.). In addition, small quantities of Armour's experimental $\overline{0}$ "improved" beef and pork H.P. Acthar Gel were used, and a small quantity of porcine corticotropin $A_{1}$, kindly supplied by Dr. H. B. F. Dixon (for details of the nature and preparation of this hormone, see Dixon and StackDunne, 1955).

It will be apparent from what follows that the labelled $D$ potency of the commercial preparations (in units per ml.) was of little help in determining the right dose to use. N The problems of the biological assay of corticotropic ${ }^{\text {I }}$ pituitary preparations for human use are complex (see $N$ Thompson and Fisher, 1953) and are not yet solved. N It is likely that the assays will remain a problem until ${ }_{\sigma}^{\infty}$ the arrival of chemically pure corticotropin makes them unnecessary. It is the purity rather than the potency of these extracts that is relevant to this paper. We need $\Phi$ some knowledge of the purity of any foreign protein we? are to inject. The makers of corticotropins provide no 0 such information with their products. Information regarding the purity of a corticotropin could be conveyed $\stackrel{\odot}{\overparen{\Phi}}$ 
either by a statement of the physico-chemical methods employed in purification, or by a statement of the potency of the preparation in units per $\mathrm{mg}$. protein. Dr. Thompson of Armour Laboratories, Kankakee, has kindly provided the following information about the potency of the H.P. Acthar Gel preparations used, in units (U.S.P. XV) per mg. protein solid:

P80001 (beef) approx. 10 units per mg. protein. N31605

32306 (pork) approx. 40 units per mg. protein. 33307

Improved beef H.P. Acthar Gel approx. 40 units per $\mathrm{mg}$. protein.

Improved pork H.P. Acthar Gel approx. 40-60 units per mg. protein.

No such assay* has been performed on Dixon and Stack-Dunne's corticotropin $A_{1}$, but from our limited experience it is by far the most potent corticotropin, per mg. protein, that we have used. Although purity can be equated with potency per mg. protein, it does not follow that allergenicity can be so equated too, because the nature (and allergenicity) of the contaminating protein may vary from preparation to preparation.

The degree of adrenocortical stimulation achieved was measured by the assay of 17-ketogenic steroids (17 KGS; Norymberski, Stubbs, and West, 1953) or 17-hydroxycorticosteroids $(17(\mathrm{OH}) \mathrm{CS}$; Appleby, Gibson, Norymberski, and Stubbs, 1955; Appleby and Norymberski, 1955) in 24-hr specimens of urine. These assays reflect the adrenals output of cortisol in all circumstances except the following:

(1) When cortisol-like corticosteroids are being administered; in this circumstance a deduction for their contribution to the urinary metabolites measured must be made.

(2) In the rare adreno-genital syndrome, when other assay methods are called for, such as that of Appleby and Norymberski (1955).

(3) In the presence of severe renal failure when all urinary and blood levels of metabolites are effected.

A study of 3,000 assays for $17 \mathrm{KGS}$ and/or 17(OH)CS made at this centre has shown that the evidence of adrenocortical activity that they provide is always consistent with the clinical state of the patient (except of course in the circumstances enumerated above). In the past eosinophil counts and the excretion of 17-ketosteroids have been used to measure adrenocortical activity. Although both these measures do reflect the changes in adrenal cortisol output neither provides a sufficiently accurate measure for therapeutic purposes.

The routine procedure for treatment has been to administer by intramuscular injection a dose of corticotropin that will maintain a daily urinary output of $17 \mathrm{KGS}$ or $17(\mathrm{OH}) \mathrm{CS}$ between $20 \mathrm{mg}$. and $40 \mathrm{mg}$.; the level aimed at depending upon the severity of the

* In the U.S.P.(XV) assay the corticotropin is given subcutaneously. The unit bears no direct relation to the international unit which is The unit bears no direct relation to the international unit which is
based on an intravenous assay. In the latter assay Dixon and Stack-Dunne (1955) found their corticotropin $A_{1}$ to have approximately 70 units per $\mathrm{mg}$. protein. disease process at the time. Some of the charts reproduced below will show how difficult this is to achieve. Assays on 24-hr urine collections were made at approximately 5-day intervals until a constant stimulation at the required level was achieved. Thereafter assays were made monthly unless the patients' clinical state suggested that a rise or fall in stimulation had occurred. If a fall had occurred the dose was raised and further assays performed. Acquired resistance was assumed to have developed if the assays confirmed a major decline in stimulation. The completeness of all $24-\mathrm{hr}$ specimens were checked by routine creatinine estimations and constant vigilance was maintained in the laboratory to avoid and detect any errors that might occur in the analytical procedures employed in the $17 \mathrm{KGS}$ and $17(\mathrm{OH}) \mathrm{CS}$ assays.

A group of 51 patients, all suffering initially from severe rheumatoid arthritis or ankylosing spondylitis, was treated by continuous adrenocortical stimulation therapy:

$\begin{array}{lllr}\text { For } 1 \text { month or more } & \ldots & \ldots & 51 \\ \text { For } 6 \text { months or more } & \ldots & \ldots & 42 \\ \text { For } 12 \text { months or more } & \ldots & \ldots & 28 \\ \text { For } 24 \text { months or more } & \ldots & \ldots & 14 \\ \text { For } 36 \text { months or more } & \ldots & \ldots & 2\end{array}$

\section{Results}

(1) Initially, in all 51 patients, the administration of corticotropin caused adrenocortical stimulation.

(2) 42 patients subsequently acquired resistance to one or more preparations of corticotropin:

$\begin{array}{lllr}\text { to two preparations } & . . & \ldots & 13 \\ \text { to three preparations } & . . & . . & 7 \\ \text { to four preparations } & . . & . . & 3 \\ \text { to five preparations } & . & . & 1 \\ \text { to six preparations } & . . & . . & 1\end{array}$

It should be pointed out that these findings did not result from an experiment with six preparations of corticotropin given to 51 patients, but were the findings incidental to a therapeutic trial extending over 3 years during which time many different batches of corticotropin came and went. A distinction is made between the development of resistance to a particular preparation or batch and the possession (subsequently) of resistance to another preparation $a b$ initio.

(3) 36 patients responded to a subsequent preparation after having acquired resistance to a previous preparation.

(4) Ten patients responded to a second preparation and subsequently developed resistance to it.

(5) Eight patients responded to a third preparation after having responded and then acquired resistance to two previous preparations.

Examples.-As the evidence for these findings includes more than a thousand steroid assays and almost as many sets of clinical assessments, it is obviously impracticable to present them in full. 
Instead, a number of the records, chosen to illustrate the main findings, are depicted graphically below. As some readers will not be familar with the type of adrenocortical response usually seen after the injection of potent corticotropin, the first three figures illustrate the common findings after a single injection, after injections given 12-hrly, and after injections given on alternate days.

(1) A woman aged 38 with rheumatoid arthritis gave a typical response to a single intramuscular injection of 40 units H.P. Acthar Gel (Fig. 1). The urinary output of $17(\mathrm{OH}) \mathrm{CS}$ returned to the control level within $24 \mathrm{hrs}$.

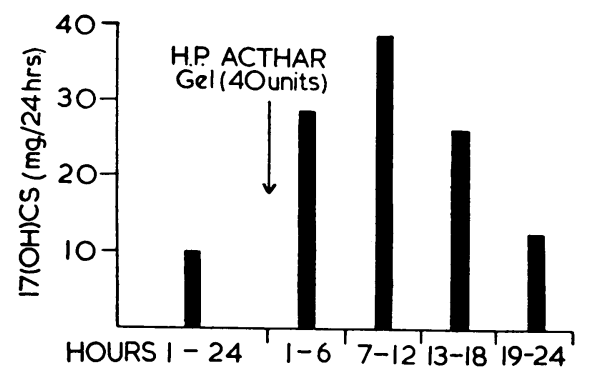

Fig. 1.-Response to a single injection of H.P. Acthar Gel in a woman aged 38 with rheumatoid arthritis.

(2) A woman aged 42 with rheumatoid arthritis was given 20 units of a long-acting preparation of corticotropin 12-hrly, which usually results in a progressive rise of adrenocortical activity (Fig. 2).

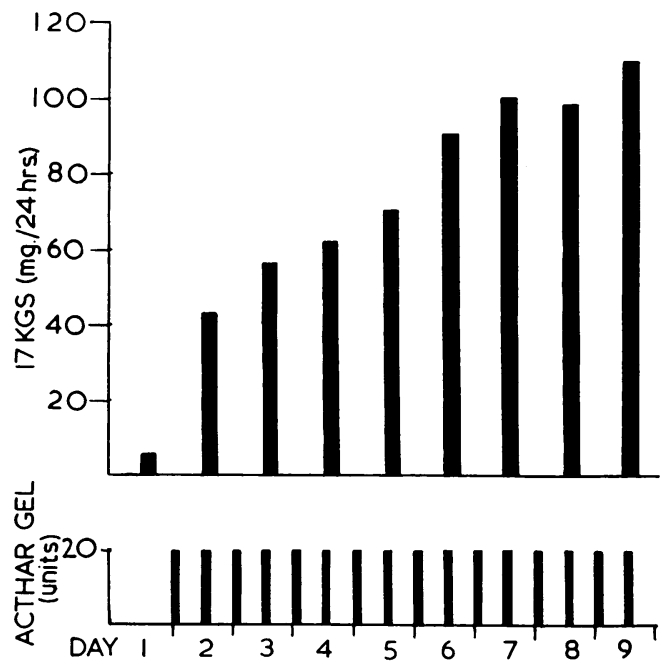

Fig. 2.-Response to 20 units of Acthar Gel given 12-hrly in a woman aged 42 with rheumatoid arthritis.

This rise is thought to be due to adrenal hypertrophy. An output of $110-120 \mathrm{mg}$. 17KGS or $17(\mathrm{OH}) \mathrm{CS}$ a day is the highest observed at this centre and may represent the upper limit of the adrenal capacity.
(3) In a man aged 45 with rheumatoid arthritis, once a steady level had been reached, the adrenals responded to injections on alternate days (Fig. 3).
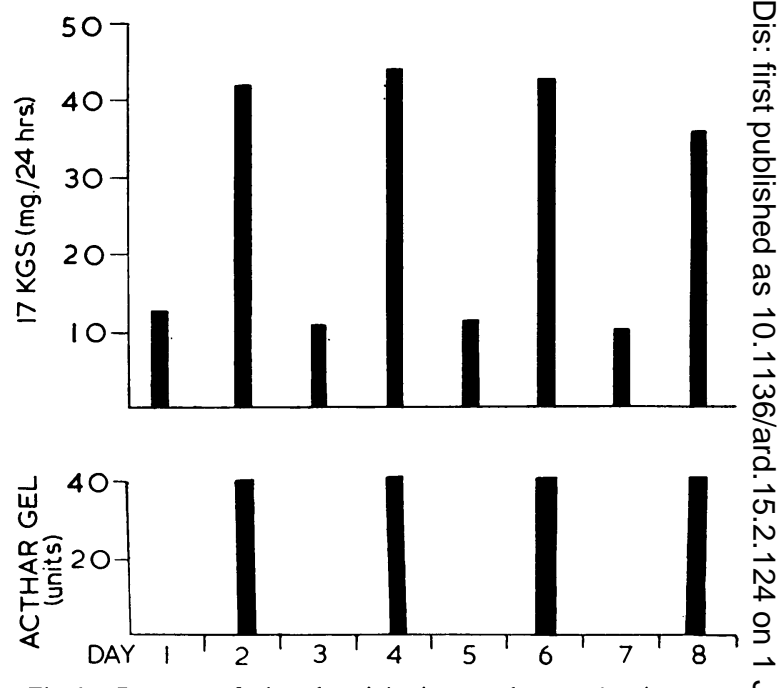

Fig. 3.- Response of adrenals to injections on alternate days in a man aged 45 with rheumatoid arthritis.

(4) A young man aged 15 with rheumatoid arthritis was observed for 3 years. Fig. 4 (opposite) shows how observations that reflect the degree of adrenocorticas activity vary in unison.

Records of the clinical assessments of the duration of "morning stiffness", of joint swelling and tenderness, and of functional capacity have been omitted, though they are also sensitive indices of changes in adrenocortical activity. When more than one assessment was made each month only the most representative figure was charted. For certain months the steroid assays are missing because the patient "forgot" to collect and bring a 24-hr specimen. During Month 3 (Period A) the corticotropin was given 12-hrly (cross-hatch). During Month 23 (Period B) the response to H.P. Acthar Gel 33307 dropped to nothing. From the 24th month onwards H.P. Acthar Gel P80001 was given (Period C).

(5) A man aged 44 had pituitary hypofunction (due to an inflammatory process) as well as rheumatoid arthritis (Fig. 5, opposite).

Organon's Cortrophin- $Z$ was given, 10 units twice daily (Period A), with an excellent response. Subsequently 20 units were given once daily (Period B), and slowly complete resistance and a severe relapse to an Addisonian state occurred. An immediate response to 10 units daily of H.P. Acthar Gel P80001 followed (Period C).

(6) A woman aged 45 with rheumatoid arthritis developed resistance to an H.P. Acthar Gel preparation and after this Organon's Cortrophin- $Z$ was, for a short time, highly effective. Within 2 weeks resistance developed to Organon's Cortrophin-Z, with local allergic reactions at the sites of injection (Fig. 6, opposite). 

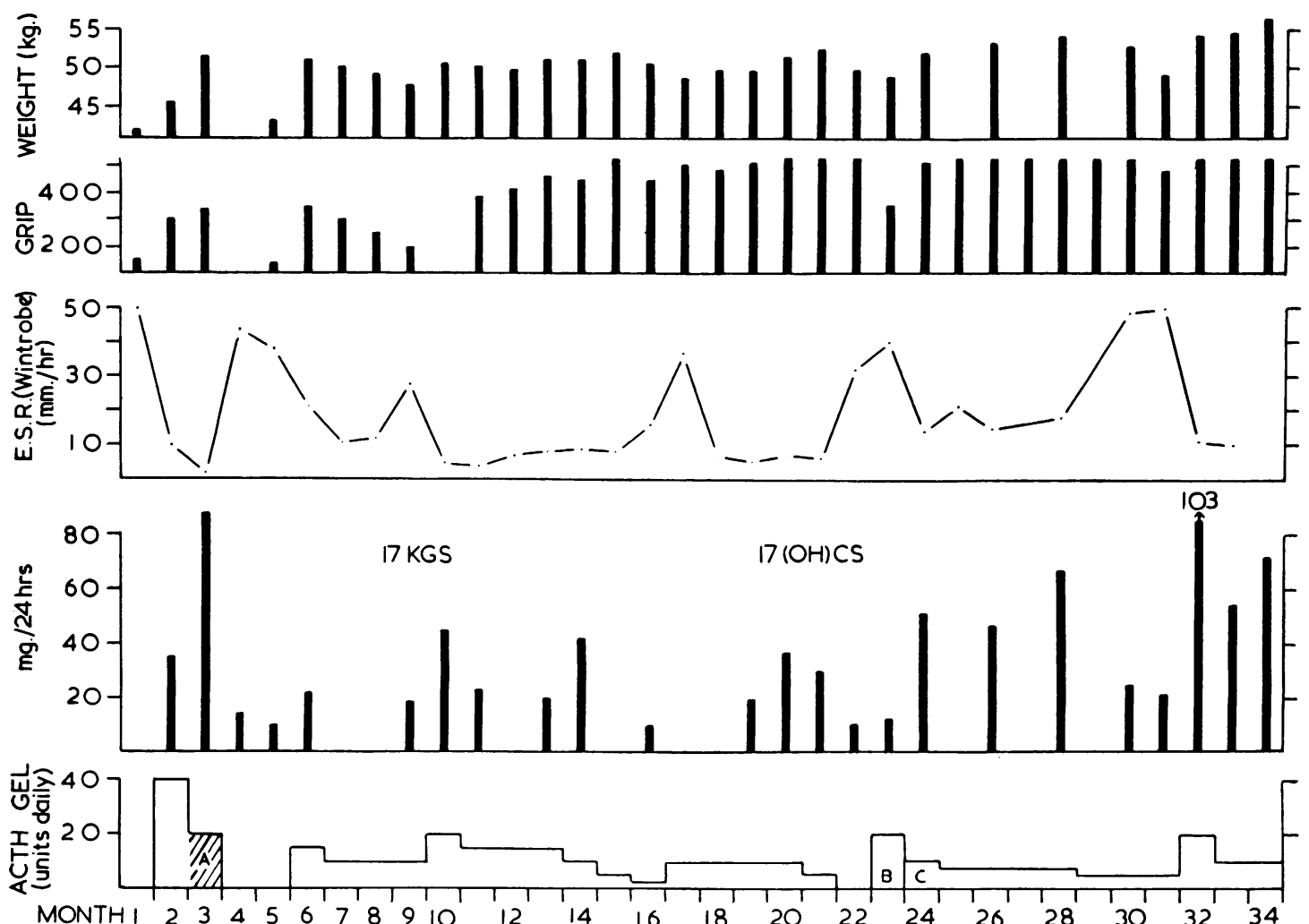

Fig. 4.-Results of 3 years' observations of a young man aged 15 to 18 years with rheumatoid arthritis, showing how different criteria of rheumatoid activity vary in unison.

A-H.P. Acthar Gel 12-hrly (cross hatch), 3rd month.

B-H.P. Acthar Gel (33307), 23rd month.

C-H.P. Acthar Gel (P80001), 24th-34th month.

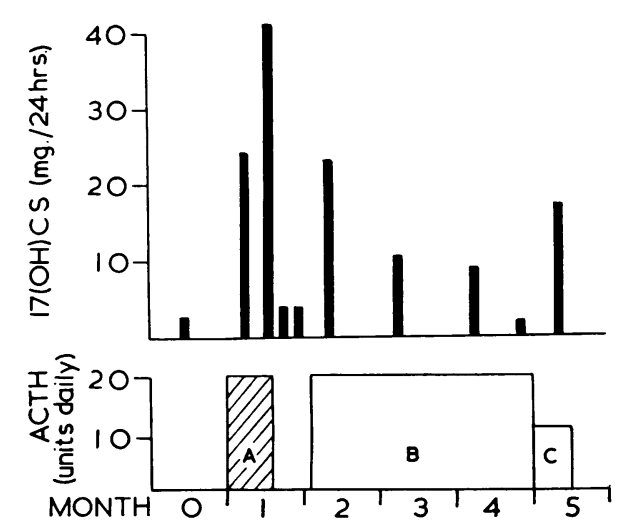

Fig. 5.-Response to Organon's Cortrophin-Z and H.P. Acthar Gel in a man aged 44 with pituitary hypofunction as well as rheumatoid arthritis.

A-Organon's Cortrophin-Z 10 units 12-hrly (cross hatch). B-Organon's Cortrophin-Z 20 units 24-hrly.

C-H.P. Acthar Gel (P80001) 10 units 24-hrly.

(7) A woman aged 50 with rheumatoid arthritis, showed a loss of response after several months of satisfactory adrenal stimulation (Period A). During Periods B, C,


Fig. 6.-Response to H.P. Acthar Gel and Organon's Cortrophin-Z in a woman aged 45 with rheumatoid arthritis.

A-H.P. Acthar Gel 30 and 20 units 24-hrly.

B-H.P. Acthar Gel 20 units 12-hrly (cross hatch).

C-Organon's Cortrophin-Z 20 units 24-hrly.

and D, 40 units of H.P. Acthar Gel, Wilson's Gel, and H.P. Acthar Gel 31605 respectively were given in divided 
doses 12-hrly-an excessive dose, yet there was no appreciable adrenocortical stimulation. Next an 8-hr intravenous infusion of ACTH was given followed by 6-hrly doses of H.P. Acthar Gel 33307-with no response at all (Fig. 7). A year later a much more highly purified ("improved") experimental preparation of H.P. Acthar Gel AL1033, P7209 was received to which the patient responded immediately (Period F). It may be suggested that during the interval of a year the patient had lost her refractoriness to corticotropin-this is unlikely, since in the 26th month she showed a positive intradermal reaction to 33307 and none to P7209 (both prepared from hog pituitaries).
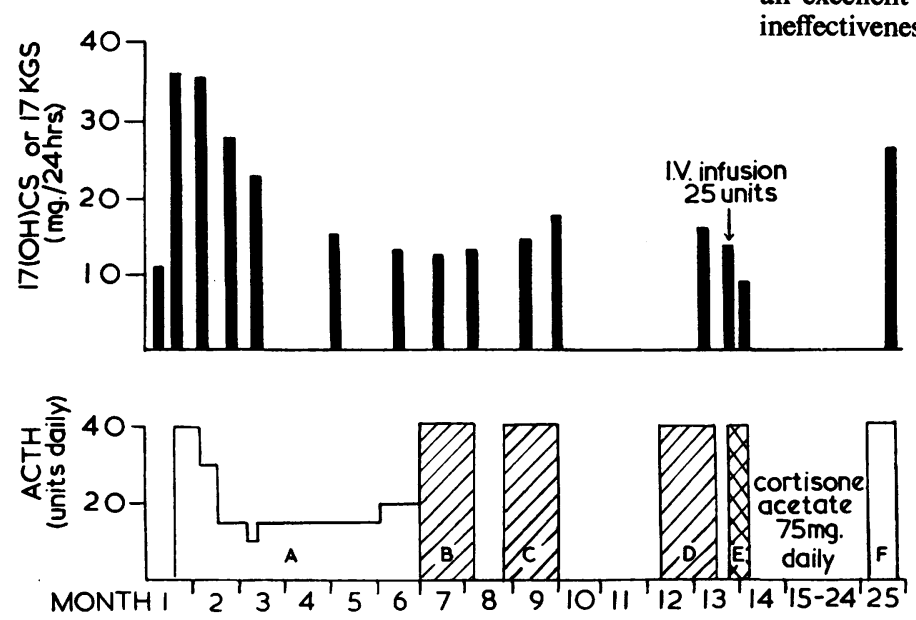

Fig. 7.-Response in a woman aged 50 with rheumatoid arthritis to a series of various preparations of Acthar Gel during a 2-year period of observation.

A-H.P. Acthar Gel 24-hrly.

B-H.P. Acthar Gel 20 units 12-hrly (cross hatch)

C-Wilson's Gel 20 units 12-hrly (cross hatch).

D-H.P. Acthar Gel (31605) 20 units 12-hrly (cross hatch).

E-H.P. Acthar Gel (33307) 10 units 6-hrly (crisscross).

F-"Improved"' H.P. Acthar Gel (AL1033, P7209) 40 units 24-hrly.

(8) A woman aged 37 with rheumatoid arthritis was given Organon's Cortrophin-Z 12-hrly (Period A). On changing to daily injections (Period B) a temporary fall was noted-this is not uncommon when dosage is sharply reduced. The development of resistance was accompanied by local allergic reactions at the site of injection (Fig. 8). During Period C H.P. Acthar Gel P80001 was given, which eventually met with the same fate. The relatively high output in the 8th month, which was in keeping with the clinical state, is not understood.
(9) $A$ woman aged 46 with rheumatoid arthritis respon- $\frac{7}{J}$ ded fairly well for 2 months (Period A) to 30 units daily $\mathbb{D}$ of an Acthar Gel preparation which had been stored at $\subseteq$ room temperature for 2 years; she was then given H.P. Acthar Gel 32306 (Period B), and resistance o developed (Fig. 9, opposite).

Next Organon's Cortrophin-Z was given in 12-hrly doses, and a poor response was noted which soon $\overline{0}$ failed completely (Period C). The white sections 든 of the columns in the upper part of the chart represent $\overline{\bar{c}}$ the contribution to the $17(\mathrm{OH}) \mathrm{CS}$ of concurrently $\frac{\mathbb{\Phi}}{\overrightarrow{\mathrm{d}}}$ administered cortisone acetate. The fourth preparation $\varrho$ to be given was H.P. Acthar Gel P80001 (Period D); ๗ an excellent response was followed by almost complete $\vec{O}$ ineffectiveness within 10 weeks.

(10) A man aged 52 with rheumatoid $\vec{\omega}$ arthritis was given Acthar Gel during the ฏ first month (Period A) with a moderate ?. clinical response (Fig. 10, opposite). $\vec{v}$

After 18 months of cortisone acetate iv therapy, Crooke's Zinc protamine $\vec{N}$

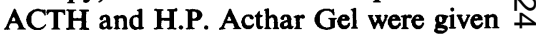
with only the slightest response (Period 음 B). Later two 8-hr infusions of ACTH were given followed by 40 units $\subseteq$ Organon's Cortrophin- $Z$ in divided doses (Period $C$ ). On 40 units of the same preparation daily (Period D), the $\overrightarrow{0}$ effectiveness soon diminished. It wकु ণ restored temporarily by giving 12-hrस doses (Period E), but had to be stopped owing to clinical relapse and locä allergic reactions at the sites of injection. H.P. Acthar Gel P80001 (Period F) given first daily and then in divided doses produced no $Q$ response. Duracton (Period $G$ ) gave rise to allergic $\overline{\bar{O}}$
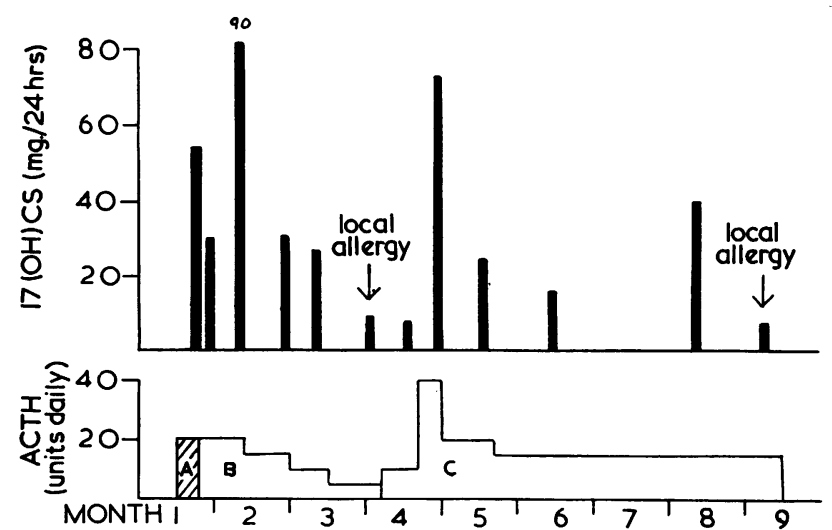

Fig. 8.-Response in a woman aged 37 with rheumatoid arthritis to Organon's Cortrophin-Z and H.P. Acthar Gel, both of which provoked allergic reactions. A-Organon's Cortrophin-Z 20 units 12-hrly (cross hatch). B-Organon's Cortrophin-Z in reduced doses 24-hrly. C-H.P. Acthar Gel (P80001) 24-hrly. 

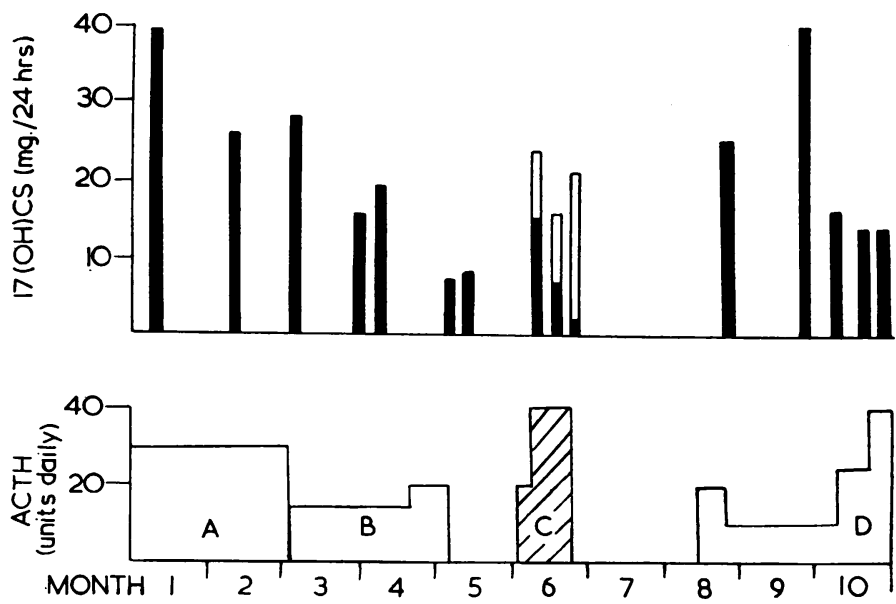

Fig. 9.-Response in a woman aged 46 with rheumatoid arthritis to various preparations of Acthar Gel and Organon's Cortrophin-Z. A-Acthar Gel which had been stored for 2 years 30 units 24-hrly.

B-H.P. Acthar Gel (32306) 24-hrly.

C-Organon's Cortrophin-Z 12-hrly (cross hatch).

D-H.P. Acthar Gel (P80001) 24-hrly.
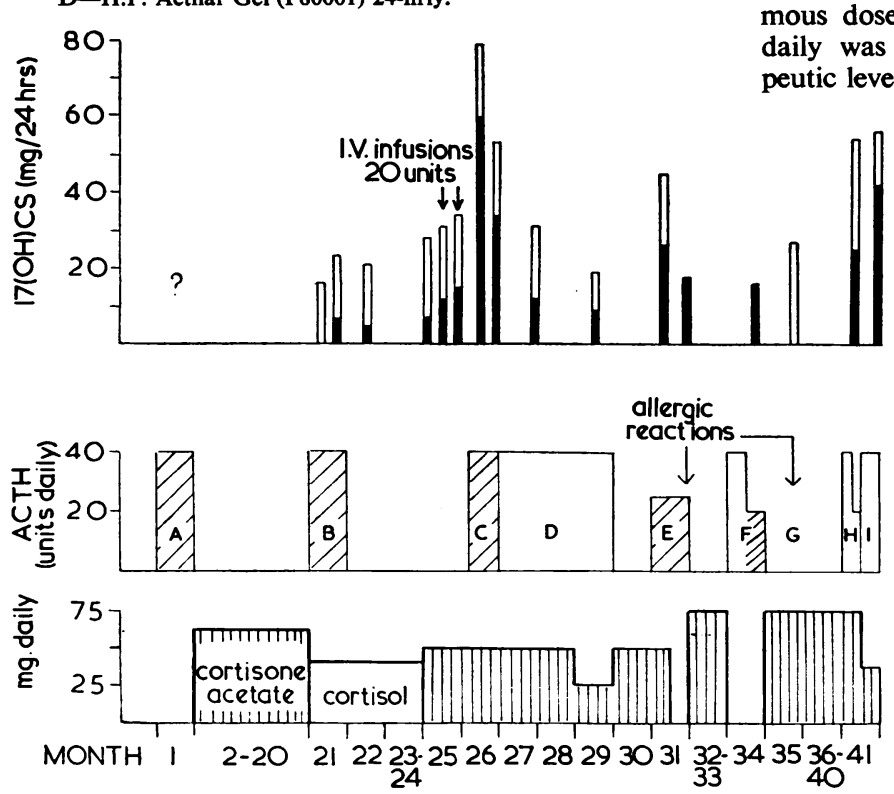

Fig. 10.-Response in a man aged 52 with rheumatoid arthritis to various preparations of Acth, H.P. Acthar Gel, Organon's Cortrophin$\mathbf{Z}$, Duracton, and Armoul's more highly purified gels given in conjunction with cortisone acetate and cortisol.

A-Acthar gel 40 units 12-hrly (cross hatch).

B-Crooke's Zinc protamine Acth and H.P. Acthar Gel 40 units 12-hrly (cross hatch).

C-Organon's Cortrophin-Z 40 units 12-hrly (cross hatch). D-Organon's Cortrophin-Z 40 units 24-hrly.

E-Organon's Cortrophin-Z 20 units 12-hrly (cross hatch)

F-H.P. Acthar Gel (P80001) 40 units 24-hrly, followed by 20 units 12-hrly (cross hatch).

G-Duracton.

H-Armour's more highly purified beef Acthar Gel 24-hrly.

I -Armour's more highly purified pork Acthar Gel 24-hrly. reactions immediately. Finally Armour's more highly purified experimental beef and pork Acthar Gels were given with a good response in each case (Periods $\mathbf{H}$ and I).

(11) A woman aged 42 with rheumatoid arthritis had had cortisone acetate for 2 years before this observation period began. During Period A Wilson's purified Gel was given and during Period B H.P. Acthar Gel; Wilson's Gel was again given in Period C but in 12-hrly doses, as was H.P. Acthar Gel in Period D. H.P. Acthar Gel P80001 was given in the 18th month (Period E), but was stopped because of ineffectiveness and local reaction at the injection site (Fig. 11, overleaf).

Finally, Duracton was given (Period F), but reaction at the site of injection began immediately. In Period $A$ it will be seen that by the 3 rd month of treatment 60 units produced no more stimulation than 20 units produced initially. Only on the enormous dose of $\mathbf{4 0}$ units of Wilson's purified Gel twice daily was adrenocortical stimulation raised to therapeutic levels.

This type of response has not been seen after prolonged cortisone acetate therapy in other patients.

Many patients lost their response to H.P. Acthar Gel N31605, and it was suggested that the batch might have been losing its potency through prolonged storage.

(12) A man aged 49 with rheumatoid arthritis, however, continued to respond normally to 31605 (Period A) until the supply of this batch was exhausted (Fig. 12, overleaf).

This example shows how two preparations of equal unit value as judged by biological assay (U.S.P. XV) can prove to be of very different potency in man, since this patient's response to H.P. Acthar Gel P80001 was quite different (Period B).

\section{Allergic Reactions}

Local reactions at the site of injection occurred in seventeen patients. The reactions usually appeared after 1 to 2 hours and consisted of an area of induration 3 to $4 \mathrm{~cm}$. across, either subcutaneous or intramuscular, which "burnt" for some hours and slowly disappeared in 6-24 hrs. All the 51 patients received H.P. Acthar Gel for more than a month and six developed local reactions. Of seventeen patients who received Organon's Cortrophin-Z 


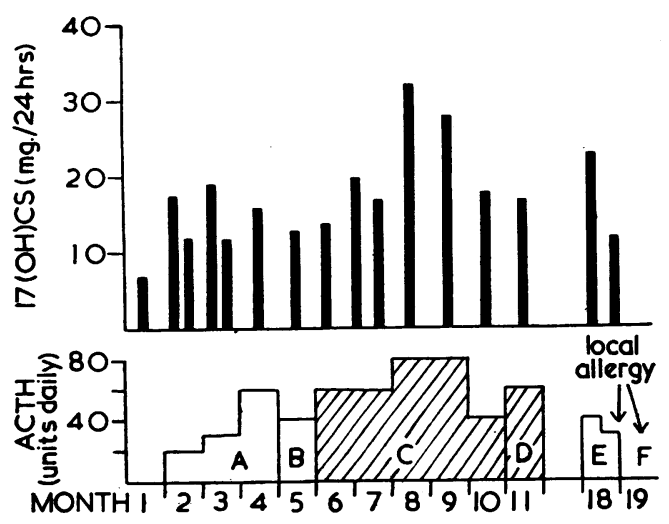

Fig. 11.-Response in a woman aged 42 with rheumatoid arthritis, who had been given cortisone acetate for 2 years before this observation period began, to various preparations of Acthar Gel and

A-Wilson's Gel 24-hrly. Duracton.

B-H.P. Acthar Gel 40 units 24-hrly.

C-Wilson's Gel 12-hrly (cross hatch).

D-H.P. Acthar Gel 60 units 12 hrly (cross hatch).

E-H.P. Acthar Gel (P80001) 24-hrly.

F-Duracton.
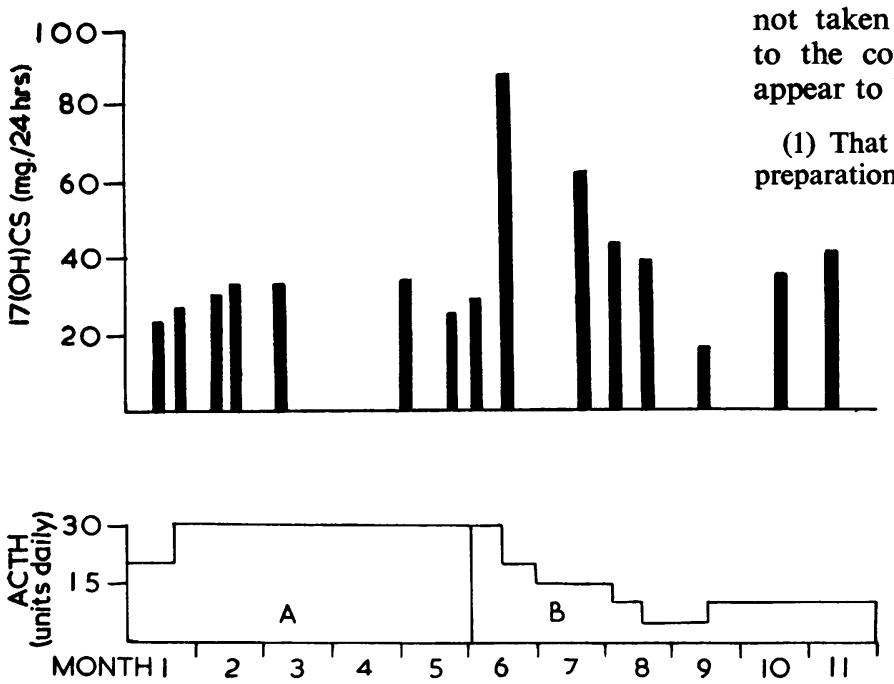

Fig. 12.- Response in a man aged 49 with rheumatoid arthritis to H.P. Acthar Gel 31605 and P80001.

A-H.P. Acthar Gel (31605) 24-hrly.

B-H.P. Acthar Gel (P80001) 24-hrly.

(Batches OA57 and OA61), only nine received it for more than one month, yet ten of the seventeen developed local allergic reactions.

General reactions, apart from anaphylactic shock, were difficult to be sure of in the patients studied, since the appearance of the allergic reactions was always accompanied by a fall in adrenocortical stimulation and a relapse of symptoms. Although no firm evidence can be provided that any of the $\frac{D}{\tau}$ patients were made ill by receiving allergenic $\stackrel{\widetilde{\Phi}}{\triangle}$ ineffective injections of corticotropin, the impression 3 was gained that in a number of instances this was so. One spondylitic patient had tense knee effusions. during ineffective H.P. Acthar Gel therapy which $\overrightarrow{\vec{F}}$ were much easier when the treatment stopped $\overrightarrow{0}$ Another patient became ill and had diarrhoea, while $\frac{-}{\circ}$ she persisted in giving herself Organon's Cortrophin- $\overline{\bar{c}}$. $\mathbf{Z}$ which was causing local reactions. The patient $\widetilde{\Phi}$ referred to in Fig. 5, on losing his response to Cortrophin-Z, developed profuse lesions on his ${ }^{\infty}$ hands, legs and feet, resembling those seen in $\overrightarrow{0}$ disseminated lupus erythematosus. He died some months later as the result of a pulmonary embolus $\omega_{\sigma}$ and the kidney showed lesions of polyarteritis nodosa.

Many patients were tested for intradermal $\vec{G}$ sensitivity to several preparations of corticotropin.? The work of Paley (1954) on dermal reactions to $\vec{N}$ insulin has shown that strict precautions and ${ }_{\circ}^{+}$ controls are necessary if much is to be deduced from the findings. Although full precautions were $\vec{c}$ not taken in the tests for intradermal sensitivity to the corticotropins, the following observations ${ }^{\Phi}$ appear to be justified:

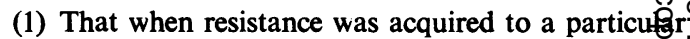
corticotropin it was not necessaray reaction.

(2) That a moderate 2 to $3 \mathrm{~cm}$. Ф delayed type reaction to H.P. Acthar Gel did not necessarily mean that $\overrightarrow{0}$ the preparation would not be effective 3 when administered in adequate $?$ dosage.

(3) That the purer the preparations of corticotropin the fewer the intra- $-\frac{0}{\delta}$ dermal reactions.

(4) That patients may give a positive intradermal reaction to a pork or beef corticotropin and yet give no음 reaction to a more highly purified corticotropin from the same species.

Corticotropin $A_{1}$.-Eleven mg. of this preparation, $N$ from pig pituitaries, was made available by Dr.W H. B. F. Dixon. One mg. was dissolved in water and used for intradermal testing and the rest waso incorporated in Armour's Acthar Gel vehicle for intramuscular injection. Sixteen patients who had $\stackrel{\text { ? }}{+}$ previously received corticotropin were tested for 0 skin sensitivity and none gave a positive reaction. $\stackrel{\circ}{\circ}$ 
Two of these patients were of particular interest and importance to this study.

(13) A woman aged 40 with rheumatoid arthritis had acquired resistance to several preparations of corticotropin and an attempt to desensitize her with porcine H.P. Acthar Gel had resulted in local allergic reactions of increasing intensity. To the experimental "improved" H.P. Acthar Gels (pork and beef) she gave positive intradermal reactions lasting for 3 days. She was then given $\mathbf{0 . 2} \mathrm{mg}$. Corticotropin $A_{1}, 12$-hrly for seven doses. Although on a maintenance dose of cortisol $(50 \mathrm{mg}$. daily), her output of $17(\mathrm{OH}) \mathrm{CS}$ during the last $24 \mathrm{hrs}$ rose to $92 \mathrm{mg}$. (a maintenance dose of $50 \mathrm{mg}$. cortisol indirectly suppresses the adrenal cortex, but does not lessen acquired resistance to administered corticotropin).

(14) A woman aged 27 with rheumatoid arthritis, who did not belong to the long-term corticotropin treatment group, had received cortisone acetate daily for 5 years, and in 1951 she had a short course of corticotropin to re-stimulate her adrenals. When this was attempted again in 1953, with H.P. Acthar Gel, she suffered an alarming anaphylactic reaction. Two and a half years later she gave a positive intradermal reaction to a $1: 10$ dilution of the "improved" H.P. Acthar Gel. Fig. 13 shows her response to Corticotropin $A_{1}$. The immediate response of the adrenal cortex and the absence of any allergic reaction was very pleasing.

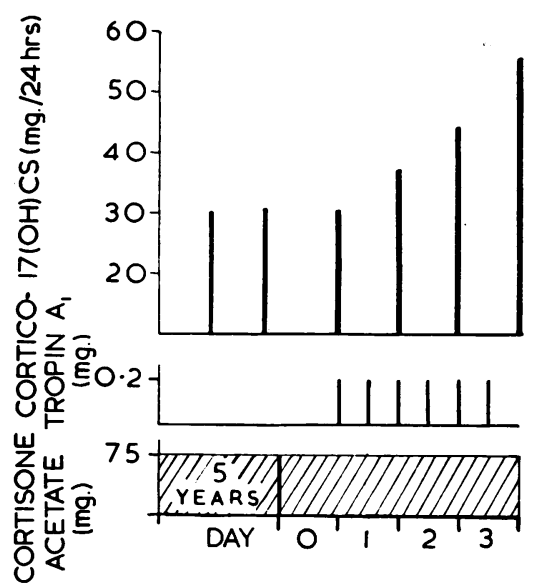

Fig. 13. - Response in a woman aged 27 with rheumatoid arthritis, who had been given cortisone acetate for 5 years, to six injections of Corticotropin $\mathbf{A}_{1} \mathbf{0} \cdot 2 \mathrm{mg}$. in 3 days.

(15) A man aged 52 with rheumatoid arthritis, who had had no cortisone to suppress his adrenals, was given Corticotropin $A_{1}$, and the response of his adrenal cortex in the first 24 hrs showed that Corticotropin $A_{1}$ was far more potent, per mg. protein, than any preparation we had previously used (Fig. 14).

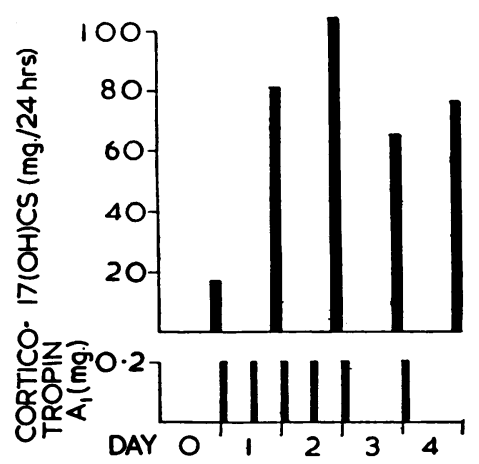

Fig. 14.-Response in a man aged 52 with rheumatoid arthritis, who had had no cortisone, to six injections of Corticotropin $A_{1} 0.2 \mathrm{mg}$. in $3 \frac{1}{2}$ days.

\section{Discussion}

There can be no doubt that the loss of effectiveness of "highly purified" corticotropin on prolonged administration is due to the development of an acquired resistance. Exhaustion of the adrenal cortex has been suggested as a possible explanation, but it is clear from the examples given that this is not the case. At this centre we have followed adrenal stimulation therapy through more than 60 patient-years and have never had cause to suspect adrenal exhaustion. The oldest patient (aged 67) appears to have the most responsive adrenal. Loss of effectiveness of corticotropin due to prolonged storage or storage at an unsuitable temperature has also been advanced to explain the falling off of effectiveness. In this study no preparation has at any time been ineffective in a previously untreated patient. The nature of the acquired resistance, however, is not known. Using the early relatively crude corticotropins, several workers have induced and demonstrated circulating antibodies, but similar studies have not been reported with the "highly purified" preparations. It is likely, of course, that cell fixed antibodies are the main cause of the acquired resistance.

Is the pure adrenocorticotropic hormone allergenic in man? Studies of the non-species specific allergic reaction induced by relatively crude corticotropins has led some workers to conclude that the hormone itself must be antigenic (Alexander, 1955). The findings reported here using "highly purified" corticotropins remove the basis on which their 
assumption was made. To be certain that it is not allergenic, a pure preparation would have to be administered for prolonged periods to patients who had shown the ability to acquire sensitivity to less pure preparations. It might prove necessary to test the pure hormone from each species used, since although the hog and the ox have the same oxytocin they have different vasopressins (du Vigneaud, Lawler, and Popenoe, 1953). There are also species differences between insulins (Brown, Sanger, and Kitai, 1955).

Nevertheless, the evidence presented above of the specific nature of the acquired resistances and of the response of the two most sensitive patients to Corticotropin $A_{1}$ does suggest very strongly that the pure hormone or hormones will not be liable to induce resistance in man. It is possible that Dr. H. B. F. Dixon's Corticotropin $A_{1}$ is, in fact, a pure hormone, i.e. containing no contaminating protein at all.

The finding of Maddock and others (1956) that non-species specific antigonadotrophins could be induced in man parallels the experience at this centre with the early crude preparations of corticotropin. Solem and Römcke (1954) found that patients who developed allergic reaction to relatively crude whale corticotropin subsequently reacted to a variety of ox pituitary products and to hog corticotropin. They did not, however, have an allergic reaction to H.P. Acthar Gel. Several of the patients referred to in this study had received the early crude corticotropin, but none has been shown to have a non-specific resistance to all corticotropins, and it can be seen from the examples given that whenever corticotropin was stopped the endogenous corticotropin was at work. Moloney and Coval (1955), using crystalline insulin with an adjuvant, induced non-species specific anti-insulin sera in guinea-pigs, but the sera did not neutralize the guinea-pigs' own insulin. It may be that there is some other explanation for the finding of Maddock and others that pituitary antigonadotrophin is apparently effective against the patients' own gonadotrophin.

Can allergenic preparations of corticotropin do harm? The crude preparations are clearly dangerous; of the "highly purified" preparations there is some doubt. In this study Organon's Cortrophin$Z$ (batches OA57 and OA61) were highly unsatisfactory and may have done harm. The H.P. Acthar Gel caused relatively few minor allergic reactions. (Nevertheless, it caused a great deal of inconvenience through the acquired resistance that developed.) It is to be hoped that purer preparations will soon be available.
Summary

Adrenocortical stimulation was maintained for prolonged periods in 51 patients by the intramuscular injection of "highly purified" corticotropin. The level of stimulation, which could be assessed roughly by clinical observation, was measured in all cases by routine urinary corticosteroid assays. During the prolonged therapy, 42 patients acquired resistance to one or more preparations of corticotropin and seventeen patients experienced allergic reactions at the sites of injection. The principal findings are presented and discussed and the following conclusions are thought to be warranted:

(1) That the generally available "highly purified" corticotropin preparations, when given intramuscularly for prolonged periods, are allergenic.

(2) That the allergenic nature of the corticotropins used resided in the contaminating or "carrier" protein that they contained.

(3) That if the pure adrenocortical hormone or hormones prove to be allergenic at all, very few patients will manifest the allergy.

(4) That no evidence has been found to suggest that, when the relatively crude corticotropins are used, anticorticotropins are formed that are able to destroy the recipient's own corticotropin.

(5) That even the "highly purified" corticotropins in use are not themselves entirely harmless. This may apple especially to patients in a permanent or temporar Addisonian state.

(6) That efforts should be made to obtain more highly purified corticotropin and that preparations of low potency should not be used.

It is recommended that a statement as to purity, measured in a recognized unit per mg. protein solid, should accompany all preparations of corticotropin.

Thanks are due to Dr. H. B. F. Dixon of the Department of Biochemistry, University of Cambridge, for the supply of Corticotropin $A_{1}$ and to Dr. R. E. Thompson of the Armour Laboratories, Kankakee, for the "improved" experimental H.P. Acthar Gel. Thanks are also due to our laboratory staff for the great care they have taken in performing more than a thousand corticosteroid assays for the patients studied, and to Dr. G. R. Newns for much clinical help.

\section{REFERENCES}

Alexander, H. L. (1955). “Reactions with Drug Therapy,” p. 136. Saunders, Philadelphia.

Appleby, J. I., Gibson, G., Norymberski, J. K., and Stubbs, R. D. (1955). Biochem. J., 60, 453.

$\overline{-}$, and Norymberski, J. K. (1955). Ibid., 60, 460.

Brown, H., Sanger, F., and Kitai, R. (1955). Ibid., 60, 556.

Dixon, H. B. F., and Stack-Dunne, M. P. (1955). Ibid., 61, 483. Forsham, P. H. (1955). "Ciba Foundation Colloquia on Endocrinology," 8, 319. Churchill, London.

Maddock, W. Ò., Leach, R. B., Tokuyama, I., Paulson, C. A., Nelson, W. O., Jungck, E. C., and Heller, C. G. (1956). "Proceedings of the Fifth International Conference on Planned Parenthood." Tokyo (in the press). 


\section{ACQUIRED RESISTANCE TO CORTICOTROPINS}

Moloney, P. J., and Coval, M. (1955). Biochem. J., 59, 179

Norymberski, J. K., Stubbs, R. D., and West, H. F. (1953). Lancet, 1,1276 .

Paley, R. G. (1954). Ibid., 2, 1249.

Solem, J. H., and Römcke, O. (1954). Acta med. scand., 149, 333.

Thompson, R. E., and Fisher, J. D. (1953). Endocrinology, 52, 496 du Vigneaud, V., Lawler, H. C., and Popenoe, E. A. (1953). J. Amer. chem. Soc., 75,4880 .

West, H. F., and Newns, G. R. (1955). Lancet, 1, 578.

\section{Résistance acquise aux corticotrophines}

\section{RÉSUMÉ}

La stimulation surrénocorticale fut maintenue durant des périodes prolongées chez 51 malades par l'injection intramusculaire de corticotrophine "hautement purifiée". Le degré de stimulation, qui pouvait être grossièrement estimé par observation clinique, fut mesuré dans tous les cas par titrage de corticostéroïdes urinaires. Durant le traitement prolongé, 42 malades acquirent une résistance à une ou à plusieurs des préparations de corticotrophine et chez 17 malades des réactions allergiques se produisirent aux points d'injections. Les résultats principaux sont présentés et discutés et les conclusions suivantes semblent être justifiées:

(1) Les préparations "hautement purifiées" de corticotrophine généralement disponibles sont allergènes quand elles sont administrées durant de longues périodes par voie intramusculaire.

(2) La nature allergène des corticotrophines utilisées réside dans la protéine contaminante ou "porteuse" qu'elles contiennent.

(3) En admettant même que l'hormone ou les hormones surrénocorticales pures soient allergènes, cette allergie se manifeste chez peu de malades.

(4) Aucune évidence n'a été trouvé pouvant suggérer que, quand des corticotrophines relativement imparfaites sont utilisées, des anti-corticotrophines se forment, capables de détruire la propre corticotrophine du sujet.

(5) Même les corticotrophines "hautement purifiées" utilisées ne sont pas tout à fait sans danger. Ceci peut s'appliquer spécialement aux malades en état d'addisonisme permanent ou temporaire.

(6) Des efforts doievent être fait en vue d'obtenir de la corticotrophine plus parfaitement purifiée et les préparations faibles ne doivent pas être utilisées.
Il est recommandé qu'une déclaration de pureté mesurée en unités souscutanées définies par $\mathrm{mg}$. de protéine solide accompagne toutes les préparations de corticotrophine.

\section{Resistencia adquirida a las corticotrofinas SUMARIO}

Se mantuvo la estimulación adrenocortical durante períodos prolongados en 51 enfermos con inyecciones intramusculares de corticotrofina "altamente purificada". El grado de estimulación, que se podía estimar aproximadamente por observacion clínica, fué medido en todos los casos por métodos habituales de dosificación de corticoesteroides urinarios. Durante el tratamiento prolongado, 42 enfermos adquirieron resistencia a una o más preparaciones de corticotrofina y en 17 enfermos se produjeron reacciones alérgicas en sitios de inyecciones. Se presentan y se discuten los resultados principales, justificando las conclusiones siguientes:

(1) Las preparaciones "altamente purificadas" generalmente disponibles son alérgenas cuando se las administra durantes períodos prolongados por vía intramuscular.

(2) La naturaleza alérgena de las corticotrofinas empleadas se debe a las proteinas contaminantes o "portadoras" contenidas en ellas.

(3) Aunque se pudiera comprobar que la hormona o las hormonas adrenocorticales sean alérgenas, pocos enfermos manifestarían esta alergía.

(4) No se encontraron indicios algunos sugerentes que, al emplear corticotrofinas relativamente imperfectas, se formasen anticorticotrofinas capaces de destrozar las corticotrofinas propias del sujeto.

(5) Hasta las corticotrofinas "altamente purificadas" en empleo presente no son enteramente sin peligro. Esto se aplica en particular a enfermos en estado de addisonismo permanente o temporario.

(6) Esfuerzos se deben hacer para obtener la corticotrofina de mayor pureza y no se deben emplear preparaciones de poca fuerza.

Se recomenda que una declaración de pureza medida por unidades subcutáneas definidas por miligramo de proteina sólida acompañe todas las preparaciones de corticotrofina. 